\title{
Aspirin as an Adjunctive Pharmacologic Therapy Option for COVID-19: Anti-Inflammatory, Antithrombotic, and Antiviral Effects All in One Agent
}

\author{
Udaya S Tantry ${ }^{\prime}{ }^{\prime}$ \\ Karsten Schror ${ }^{2}$ \\ Eliano Pio Navarese ${ }^{3}$ \\ Young-Hoon Jeong ${ }^{4}$ \\ Jacek Kubica ${ }^{3}$ \\ Kevin P Bliden' \\ Paul A Gurbel'

\begin{abstract}
'Sinai Center for Thrombosis Research Baltimore, LifeBridge Health, Baltimore, and Clinical Pharmacology, HeinrichHeine-University, Düsseldorf, Germany; ${ }^{3}$ Department of Cardiology and Internal Medicine, Nicolaus Copernicus University, Bydgoszcz, Poland; ${ }^{4}$ Department of Internal Medicine, Gyeongsang National University School of Medicine and Cardiovascular Center, Gyeongsang National University Changwon Hospital, Changwon, South Korea
\end{abstract} \\ and Drug Development, Sinai Hospital of \\ MD, USA; ${ }^{2}$ Department of Pharmacology
}

Introduction: Pharmacologic therapy options for COVID-19 should include antiviral, antiinflammatory, and anticoagulant agents. With the limited effectiveness, currently available virusdirected therapies may have a substantial impact on global health due to continued reports of mutant variants affecting repeated waves of COVID-19 around the world.

Methods: We searched articles pertaining to aspirin, COVID-19, acute lung injury and pharmacology in PubMed and provide a comprehensive appraisal of potential use of aspirin in the management of patients with COVID-19. The scope of this article is to provide an overview of the rationale and currently available clinical evidence that supports aspirin as an effective therapeutic option in COVID-19.

Results: Experimental and clinical evidence are available for the potential use of aspirin in patients with COVID-19.

Discussion: Aspirin targets the intracellular signaling pathway that is essential for viral replication, and resultant inflammatory responses, hypercoagulability, and platelet activation. With these multiple benefits, aspirin can be a credible adjunctive therapeutic option for the treatment of COVID-19. In addition, inhaled formulation with its rapid effects may enhance direct delivery to the lung, which is the key organ damaged in COVID-19 during the critical initial course of the disease, whereas the 150-325 mg/day can be used for long-term treatment to prevent thrombotic event occurrences. Being economical and widely available, aspirin can be exploited globally, particularly in underserved communities and remote areas of the world to combat the ongoing COVID-19 pandemic.

Keywords: COVID-19, acetyl salicylic acid, platelets, inflammation, lungs, acute respiratory syndrome

\section{Introduction}

\section{COVID-19 and Host Response}

The rapid development of coronavirus disease-19 (COVID-19) as an acute lung injury/acute respiratory distress syndrome (ALI/ARDS) progressing to death has become a daunting challenge to manage. Options such as treatment with antiviral, anti-inflammatory, and anticoagulant agents and mechanical ventilation may not be readily available in underserved communities and in remote areas of the world. Within this framework, the degree of efficacy of most strategies assessed individually is variable ranging from low to moderate. ${ }^{1,2}$
Thrombosis Research Laboratory, Sin Center for Thrombosis Research and Drug Development, Sinai Hospital of Baltimore, LifeBridge Health, Baltimore, MD, 21215 , USA

Tel + I 410-367-2590

Fax +l 410-367-2596

Email utantry@lifebridgehealth.org 
Aspirin can influence different disease-relevant pathways during the course of COVID-19. The interplay of these distinct aspirin-mediated effects may contribute to the outcome improvement of COVID-19 patients by interfering with the viral replication as well as its antiinflammatory and antithrombotic properties. ${ }^{3}$ Currently available antiviral agents and other novel therapies that directly target the virus may exhibit limited effectiveness over time due to adaptive mutations of the viral genome. ${ }^{4}$ A limitation of virus-directed therapies may have a substantial impact on global health due to continued reports of mutant variants affecting repeated waves of COVID-19 around the world, which may further undermine the efficacy of these therapies that are also expensive. ${ }^{4}$ Therefore, it is important to explore economically feasible and readily accessible resilient mechanisms to target COVID-19. Such strategies will facilitate the treatment of patients with COVID-19 and viral mutants in remote parts of the world and underserved communities. The scope of this article is to provide a comprehensive description of the rationale and supporting clinical evidence of aspirin as a multimodal therapeutic option in COVID-19.

\section{Mechanisms of Virus Entry into the Host Cells and Inflammatory Cascade}

During the initial steps of SARS-CoV-2 (severe acute respiratory syndrome- coronavirus-2) infection, spike (S)glycoprotein on the surface of the SARS-CoV-2 binds to the angiotensin-converting enzyme receptor 2 (ACE2). Transmembrane protease serine (TMPRSS) 2 is involved in $\mathrm{S}$ protein priming that facilitates virus entry into the host cell (endocytosis). The ACE2 receptor and TMPRSS2 are highly expressed on the surface of alveolar cells in the lower respiratory tract. ${ }^{5,6}$ After viral release into the cytoplasm of the host cell, the SARS-CoV-2 viral genome produces two polyproteins (PPs). These PPs help control the host cell machinery in a "hostile takeover" resulting in their own rapid translation and replication in endosomes. Mature virions are later released by exocytosis and can bind to TLR4 on host cell membrane to trigger the activation of the intracellular inhibitor of kappa B kinase (IKK) complexes. ${ }^{5}$ The viral ribonucleic acid (RNAs) bind to Toll like (TLR) receptors (TLR3 for double-stranded RNAs or TLR7/8 for single-stranded RNAs) on endosomal membrane leading to the activation of transcription of the interferon-regulatory factor (IRF) family and subsequently type I interferon and also induce NF- $\kappa \mathrm{B}$ (nuclear factor- $\mathrm{KB}$ ) activation (Figure 1). The activation of IKK results in the phosphorylation of the cytoplasmic inhibitor factor, $\mathrm{IkB} \alpha$ triggering its ubiquitination and degradation by the 26S proteasome. Simultaneously, NF$\kappa \mathrm{B}$ (a heterodimer complex consisting of protein subunits $\mathrm{p} 50$ and $\mathrm{p} 65$ ) is released from $\mathrm{IkB} \alpha$, then it translocate into the nucleus and induces transcription of various genes coding for pro-inflammatory proteins such as cytokines, chemokines, adhesion molecules, acute phase proteins, and growth factors. ${ }^{7-9}$

These cytokines activate inflammatory leukocytes (neutrophils, macrophages) and trigger their infiltration into the alveolar space further boosting the generation and release of large quantities of inflammatory cytokines in a "cytokine storm". Activated macrophages express tissue factor that activates coagulation leading to systemic hypercoagulability (Figure 2). ${ }^{7,10}$ COVID-19-induced coagulopathy (CIC) is characterized by neutrophilia and elevated levels of interleukin-6, C-reactive protein, D-dimer, FVIII, and fibrinogen. The latter processes induce inflammatory cell activation and infiltration, vascular leakage, pulmonary edema, and rapid progress to ARDS, multiorgan dysfunction, and death in a substantial percentage of patients. Similarly, cytokine storm and hypercoagulability have been shown to be associated with pulmonary microthrombosis and eventually apoptosis of pulmonary cells. $^{11}$

\section{Role of Platelets in COVID-19}

In addition, multiple lines of evidence point towards an essential role of platelets during COVID-19 ALI/ARDS (7-10). Platelets play a critical role in hemostasis, thrombosis, and innate immune and inflammatory responses. Platelet-leukocyte aggregate formation and abnormal leukocyte accumulation in the lungs, hypercoagulability, and elevated levels of thromboxane $\mathrm{A}_{2}$, P-selectin and biomarkers of inflammation have been demonstrated in animal models of ALI/ARDS. ${ }^{12}$ Direct binding of SARS-CoV-2 to platelets through ACE2 and TMPRSS2 expressed on platelets has been demonstrated in in vitro studies. Elevated platelet aggregation, glycoprotein (GP) IIb/IIIa expression at the platelet surface, P-selectin expression, and platelet granule secretion has been demonstrated in ALI/ARDS models. Subsequently, activated platelets bind to leukocytes and enhance their infiltration into the lungs to further propagate inflammation. ${ }^{13}$ Subjects suffering from viral upper respiratory tract infections have been 


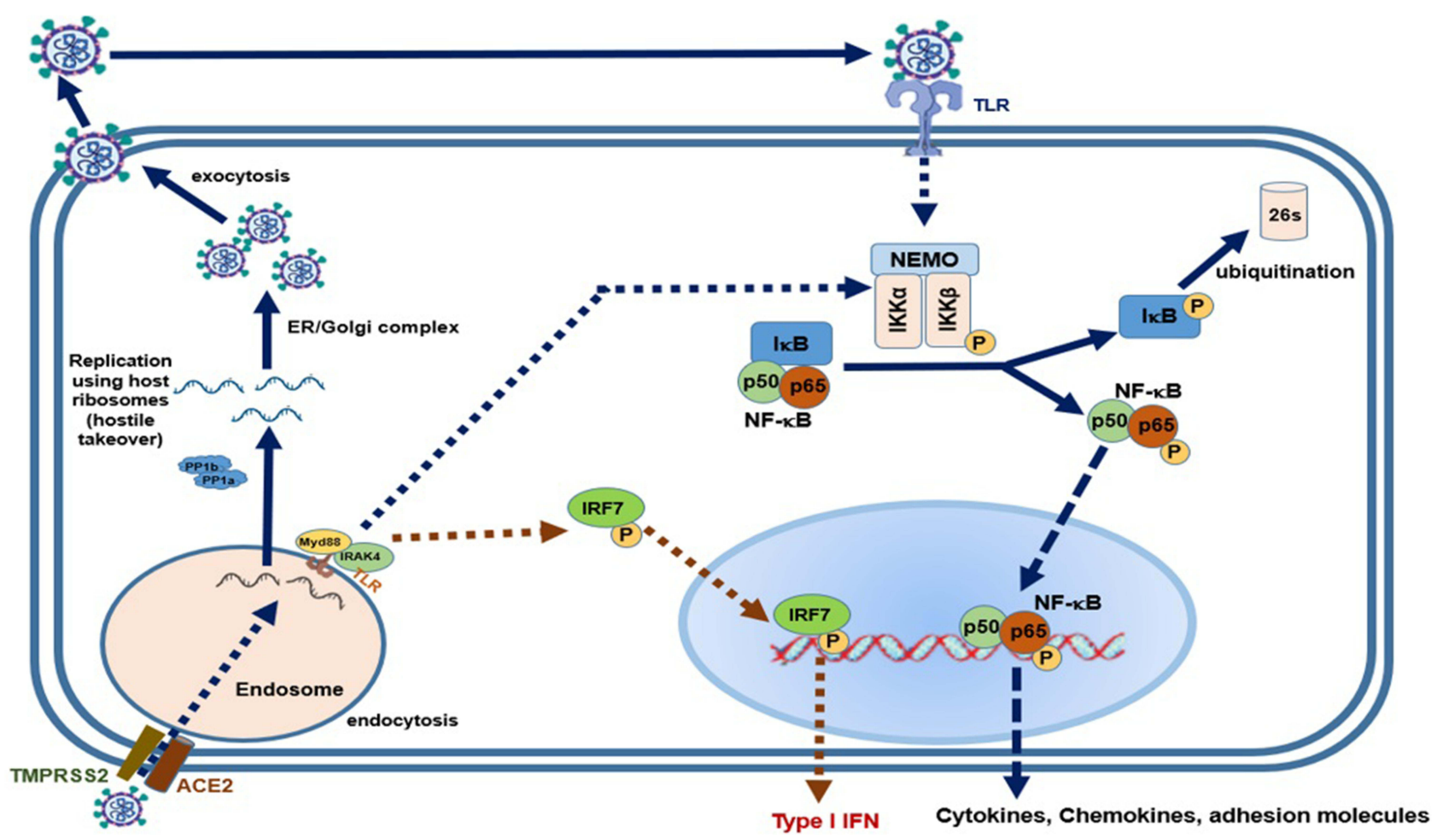

Figure I SARS-CoV-2 infection and replication inside the host cell. Initially, SARS-CoV-2 enters the host cell through binding to the ACE2 receptor and the function of TEMRSS2. The virus undergoes replication using host machinery ("hostile takeover") and the mature virus is released (exocytosis) from the host cell. Inside the endosome, the viral RNA binds to the TLR and activates IRF7 that translocate into the nucleus to induce the expression of Type I interferon. SARS-CoV-2 binding to TLR also activates IKK $\beta$ and leads to NF-kB-mediated expression of cytokines, chemokines and adhesion molecules.

Abbreviations: SARS-CoV-2, severe acute respiratory syndrome-coronavirus-2; ACE2, angiotensin converting enzyme receptor 2; TMPRS 2, transmembrane protease serine; PPs, polyproteins; RNA, ribonucleic acid; TLR, toll-like receptor; IKK $\beta$, IK $\beta$ kinase complex; NF- $\kappa B$, nuclear factor- $\kappa B$; NEMO, NF- $\kappa B$ essential modulator; IRF7, interferon regulatory transcription factor 7; ER, endoplasmic reticulum; TMPRSS2, transmembrane serine protease 2.

shown to exhibit elevated platelet P-selectin expression and heightened platelet reactivity. ${ }^{14}$ It has been hypothesized that the thrombo-inflammatory state has an important influence on the outcomes of patients with cardiovascular disease and human immunodeficiency virus infection during and after percutaneous coronary intervention. ${ }^{15}$

Megakaryocytes are precursors of platelets. Following their release from bone marrow, platelets circulate in large numbers through the lungs, where they are dynamically released. A recent study using direct imaging of lung microcirculation in mice suggested that the lungs can contribute up to $50 \%$ of total platelet release. ${ }^{16}$ Since the lungs are severely affected during COVID-19, platelet generation/function may also be severely affected. In the presence of endothelial dysfunction, elevated levels of von Willebrand Factor (VWF) expression in the lung, elevated systemic levels of fibrinogen, and activated platelets likely play a significant role in pulmonary thromboembolic event occurrences. ${ }^{17-19}$ Activated platelets stimulate neutrophils to produce neutrophil extracellular traps (NETs). NETs consist of deoxyribose nucleic acid (DNA) fibers, histones, and antimicrobial proteins that help to entrap and degrade invading bacteria and viruses (NETosis) as part of the innate immune response. However, platelet-induced NETosis can be more lethal resulting in tissue damage, hypercoagulability, and thrombosis. ${ }^{20}$ In a prospective cohort study in patients with COVID-19, elevated levels of platelet-neutrophil aggregates, plasma myeloperoxidase (MPO)-DNA complexes, platelet factor 4, and Regulated upon Activation, Normal $\mathrm{T}$ Cell Expressed and Presumably Secreted (RANTEs) have been demonstrated. Circulating NET levels correlated with the severity of COVID-19. ${ }^{20}$ Furthermore, in autopsies, the presence of NET-containing microthrombi with platelet-neutrophil infiltration in lungs again highlights the critical role of platelets in COVID-19. ${ }^{20}$ Post-mortem examination of patients with COVID-19 found a nine times higher prevalence of microvascular platelet-fibrin clots in the pulmonary vasculature than in patients with influenza virus infection. ${ }^{19}$ In vivo evaluation of the sublingual microcirculation in patients with severe COVID-19 requiring mechanical ventilation revealed microvascular thrombi in 


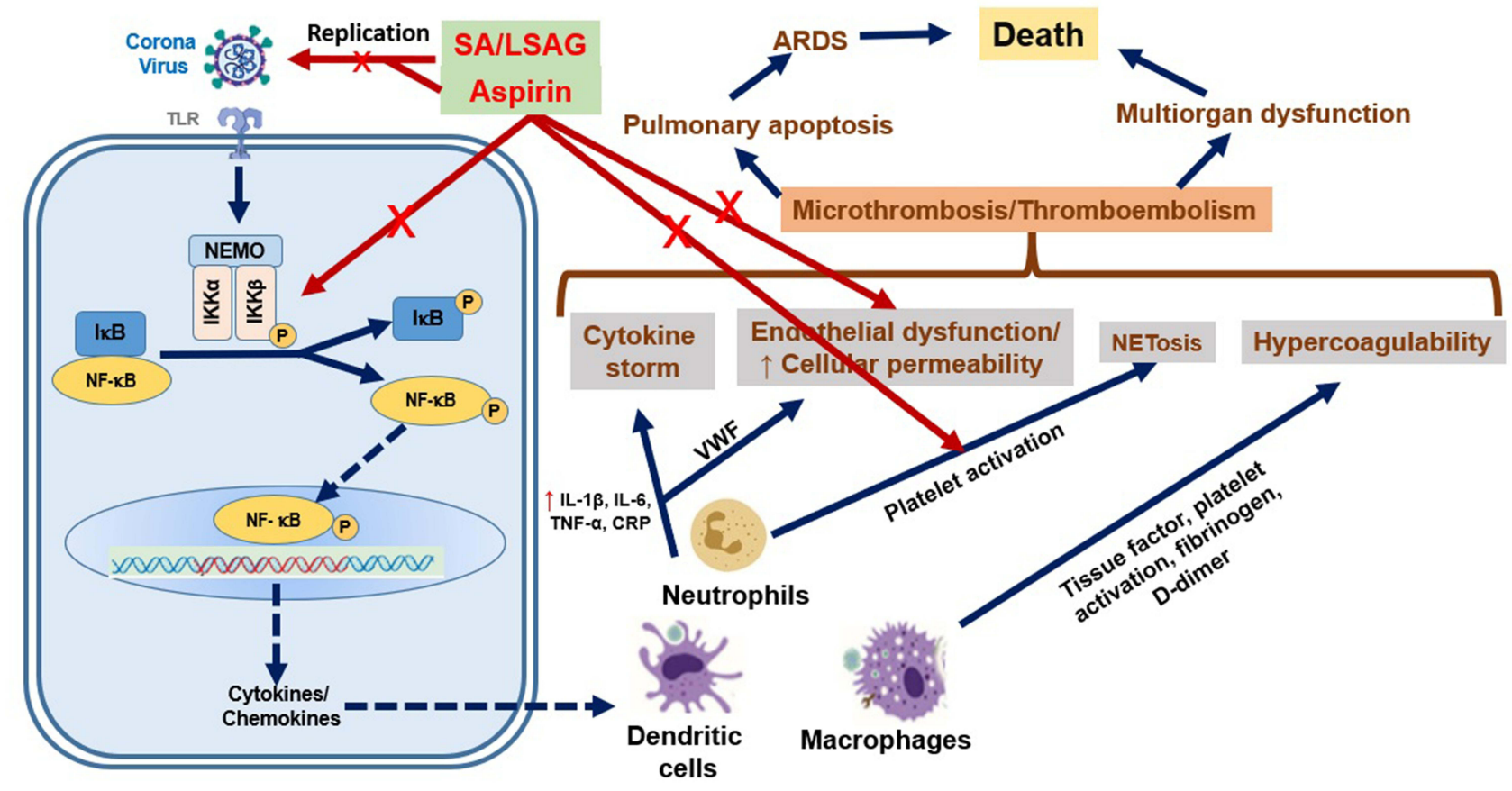

Figure 2 Host cell response to SARS-CoV-2 infection and role of aspirin in SARS-CoV-2 infection. SARS-CoV-2 induced cytokine storm, endothelial dysfunction, NETosis and hypercoagulability result in microthrombosis/thromboembolism in lungs as well as heart and kidney leading to multiorgan dysfunction, ARDS and ultimately death in a substantial percentage of patients. Aspirin/SA/LSAG can attenuate the viral replication and inhibit NF- $\mathrm{kB}$ activation and subsequent expression of cytokines and chemokines. In addition, ASA exhibits anti-inflammatory and antiplatelet effects, and attenuates NETosis, endothelial dysfunction and hypercoagulability.

Abbreviations: ASA, acetyl salicylic acid; SA, salicylic acid; LASAG, D, L-lysine-acetylsalicylate glycine; NF- $\kappa B$, nuclear factor- $\kappa B$; IL, interleukin; TNF- $\alpha$, tumor necrosis factor- $\alpha$; CRP, C-reactive protein; MCP-I, macrophage chemoattractant protein-I; ICAM-I, intercellular adhesion molecule-I; VCAM-I, vascular cell adhesion molecule-I; NETs, neutrophil extracellular traps; ARDS, acute respiratory distress syndrome.

$85 \%$ of the cases. ${ }^{20}$ Finally, the presence of microthrombi in the heart, kidneys, and liver in patients with COVID-19 may indicate widespread thrombotic microangiopathy resulting in multiorgan dysfunction. ${ }^{21-23}$

\section{Potential Role of Aspirin in COVID-19}

The totality of evidence consistently indicates that the resilience mechanism to target during COVID-19 for both prevention and treatment should involve effective and simultaneous attenuation of viral infection and replication, cytokine release, endothelial dysfunction, coagulation, fibrinolysis, and importantly, platelet function. Therefore, aspirin - an inexpensive, widely available, safe, and time-tested agent with anti-inflammatory, antithrombotic, and antiviral properties - can be a credible adjunctive therapeutic option for the treatment of COVID-19. ${ }^{24}$ Most importantly, instead of targeting the virus directly, aspirin targets the intracellular signaling pathway of the host cell that is essential for viral replication, and resultant inflammatory responses, hypercoagulability, and platelet activation that follow infection. Thus, aspirin would be predicted to be effective even in the presence of mutant virus forms. The role of aspirin may be particularly relevant in situations where more expensive therapeutic options are not readily available.

Two major underpinnings for using aspirin in COVID19 include the effect of aspirin on the inhibition of cyclooxygenase (COX)-1 and COX-2 enzymes by acetylation and the effect on NF- $\mathrm{BB}$ by salicylic acid. ${ }^{25}$ The acetyl group of aspirin binds to the serine residue (Ser529) in platelet COX-1 irreversibly and noncompetitively for the lifespan of platelets, and thereby inhibits the eventual generation of an important platelet agonist, thromboxane $(\mathrm{Tx}) \mathrm{A}_{2}$, and platelet activation. An antithrombotic effect of aspirin has been primarily attributed to the inhibition of the platelet COX-1 enzyme that occurs at low doses $(75-81 \mathrm{mg} /$ day). In vitro studies indicate that the inhibitory potency of aspirin against COX-1 and COX-2 is similar in molar terms ${ }^{26,27}$ However, in vivo higher molar concentrations of aspirin are required because of the significant protein (COX) turnover rate of nucleated cells as opposed to the apparently missing turnover of the anucleated platelets. Thus, within the short half-life of aspirin in the circulation, amounting to 20-30 min, enough new enzyme protein might have been synthesized that escapes the acetylation by aspirin. COX-1 inhibition results in the 
direct inhibition of prostaglandin intermediate endoperoxide generation in the platelet that is upstream from the generation of $\mathrm{TxA}_{2}$ by thromboxane synthase. ${ }^{28}$ These inhibitory properties are reflected in reduced excretion of the stable thromboxane metabolite, urine 11-dehydro thromboxane $\mathrm{B}_{2}$ (u11-dh $\mathrm{TxB}_{2}$ ). Thus, u11-dh $\mathrm{TxB}_{2}$ represents the whole-body $\mathrm{COX}$ inhibitory response induced by aspirin. ${ }^{29-31}$ The independent relation of urine u11-dh $\mathrm{TxB}_{2}$ to adverse outcomes in patients with cardiovascular disease and diabetes treated with aspirin has been clearly demonstrated in major clinical trials. ${ }^{32-34}$

At higher doses, aspirin also inhibits the COX-2 enzyme that is expressed during inflammatory conditions by acetylating the homologous Ser516 residue. ${ }^{26,27}$ The latter effect results in the inhibition of pro-inflammatory prostaglandin E2 (PGE2) generation. The inhibition of COX-2 by aspirin also results in the inhibition of prostaglandin intermediate endoperoxide synthesis that participates in $\mathrm{TxA}_{2}$ generation through transcellular biosynthesis. ${ }^{25}$ Acetylated COX-2 can convert arachidonic acid to 15-epoxy-lipoxin A4, also known as aspirintriggered lipoxin (ATL). Lipoxins and aspirin via ATL inhibit leukocyte-endothelial interactions by stimulating nitric oxide release, decrease vascular permeability, and attenuate endothelial dysfunction by improving oxygen defense. $^{35-38}$ In addition, the aspirin-acetylated COX-2 enzyme generates aspirin-triggered resolving D1 (ATRvD1) molecule. ${ }^{39}$ In an acid-initiated murine lung injury model, administration of AT-RvD1 significantly decreased bronchoalveolar lavage fluid neutrophils, platelet-neutrophil interactions, the release of cytokines and p-selectin, and nuclear translocation of NF- $\mathrm{kB}$-phosphorylated p 65 as determined by immunohistochemistry of lung sections. ${ }^{40}$

Aspirin and salicylic acid at $1-5 \mathrm{mM}$ concentrations have been shown to inhibit NF- $\kappa B$ activation and NF- $\mathrm{BB}$ induced inflammatory cytokine generation. ${ }^{7,41}$ This involves transcriptional activation of differentially regulated transcription factors, including NFkB, and is apparently due to nonselective kinase inhibition. ${ }^{42}$ It has been demonstrated that aspirin and salicylic acid inhibit IKK activity by blocking ATP binding to IKK- $\beta .^{41-43}$ Aspirin has been shown to attenuate thrombin generation and factor XIII activation in a microvascular injury model as well as thrombin-induced venous thromboembolism via inhibition of thromboxane action. ${ }^{44-46}$ Aspirin can also enhance fibrin clot permeability and clot lysis by acetylating lysine residues in fibrin at high doses. ${ }^{47,48}$ In addition, aspirin non-specifically acetylates a variety of proteins and nucleic acids at micromolar concentrations. ${ }^{49-51}$

In an in vitro experiment with phorbol 12-myristate 13acetate (PMA)- or tumor necrosis factor- $\alpha$ (TNF- $\alpha$ )activated human neutrophils, $5 \mathrm{mM}$ aspirin was associated with a significant reduction in NET release. This reduction was correlated with a significant reduction in the phosphorylation of the NF- $\mathrm{kB}$ p65 subunit indicating aspirin can attenuate NETs release from neutrophils by inhibiting $\mathrm{NF}-\kappa \mathrm{B} .{ }^{52}$ Aspirin was shown to inhibit reactive oxygen species generation, neutrophil infiltration, macrophage generation, and lung edema in a hyperoxia-induced lung injury model in NF- $\mathrm{kB}$-luciferase transgenic mice. ${ }^{53}$

With respect to direct antiviral effects of aspirin, in vitro and in vivo studies shown that aspirin can effectively block influenza virus infection. This antiviral effect has been attributed to the inhibition of viral replication and propagation through NF-kB inhibition. ${ }^{54,55}$ Antiviral effect of the D, L-lysine-acetylsalicylate glycine (LASAG), an aerosolized formulation of aspirin, is discussed later.

\section{Experimental Evidences}

Animal studies have shown that aspirin can prevent ARDS by decreasing neutrophil activation and recruitment in the lung, TNF- $\alpha$ expression in pulmonary intravascular macrophages, plasma $\mathrm{TxB}_{2}$ levels, and platelet aggregation in the lungs. ${ }^{56-58}$ Finally, a meta-analysis of studies in animal models of ARDS revealed that aspirin administration was associated with improved oxygenation, diminished lung edema and inflammation, and increased survival in some studies. ${ }^{56}$ All these data indicate that aspirin has the potential to attenuate COVID-19 induced excessive immune activation, cytokine storm, hypercoagulability, and multiorgan damage and thus, favorably affects clinical outcomes.

\section{Benefit of Aspirin in Patients with ARDS}

Some observational studies suggested the benefit of prior aspirin use in reducing the risk associated with ALI/ ARDS. ${ }^{60-64}$ Importantly, in a recent multivariate analysis of seven studies with 6764 at-risk patients, prior aspirin use compared to no aspirin use was associated with a significantly lower incidence of ARDS (OR, 0.78; 95\% $\mathrm{CI}=0.64-96 ; \mathrm{p}=0.018$ ), but not hospital mortality $(\mathrm{OR}=, 0.88 ; 95 \% \mathrm{CI}=0.73-1.07 ; \mathrm{p}=0.20) .{ }^{65}$ In a study of 839 severely injured blunt trauma patients at risk for 
multiple organ failure, prehospital antiplatelet therapy (16\% of the patients on aspirin) was associated with a decreased risk of lung dysfunction and multiple-organ failure. ${ }^{66}$ Concurrent use of statin and aspirin, but not aspirin alone, was shown to reduce the risk of ARDS in a cohort of 575 critically ill hospitalized patients. ${ }^{67} \mathrm{In}$ a selected cohort of 1149 critically ill hospitalized patients, a lower prevalence of ARDS was observed in patients who were already on aspirin therapy ( $27 \%$ vs $34 \%$ ), and the effect persisted in a multivariate analysis (odds ratio [OR] $=0.66 ; 95 \%$ confidence interval $[\mathrm{CI}]=0.46-94) .{ }^{68} \mathrm{In}$ a propensity-adjusted analysis involving 6823 patients, aspirin use prior to sepsis onset was associated with a $7 \%$ reduction in mortality $(\mathrm{p}=0.005)$ (Table 1$){ }^{69}$

Aspirin administration for prior 7 days significantly augmented the plasma pro-inflammatory cytokine levels, but not anti-inflammatory cytokine levels in healthy subjects who were administered with Escherichia coli endotoxin. There was no additional anti-inflammatory effect with aspirin plus a $\mathrm{P} 2 \mathrm{Y}_{12}$ receptor inhibitor. ${ }^{70}$

\section{Preliminary Data Demonstrating the Benefit of Aspirin in Patients with COVID- I 9 \\ Pharmacodynamic Studies}

In a prospective observational study of hospitalized patients with COVID-19 $(n=120)$, those who were on aspirin therapy had lower u11-dh $\mathrm{TxB}_{2}$ levels than patients not on aspirin $(3760 \pm 2295$ versus $13,125 \pm 11,474 \mathrm{pg} / \mathrm{mg}$ creatinine, $p=0.003$ ). An inadequate therapeutic aspirin response based on $>1520 \mathrm{pg}$ u11-dh $\mathrm{TxB}_{2} / \mathrm{mg}$ creatinine cut-off was observed in $91 \%$ of the patients with COVID-19 on $81 \mathrm{mg}$ daily aspirin and $50 \%$ of the patients with COVID-19 on $\geq 162 \mathrm{mg}$ daily aspirin. ${ }^{71}$ The frequency of thromboinflammation as indicated by $>4200 \mathrm{pg}$ u $11-\mathrm{dh}^{\mathrm{TxB}} \mathrm{B}_{2} / \mathrm{mg}$ creatinine was $81 \%$ in patients with COVID- 19 not on aspirin, $55 \%$ in patients on $81 \mathrm{mg}$ daily aspirin, and $25 \%$ in patients on $\geq 162 \mathrm{mg}$ daily aspirin. Moreover, only $17 \%$ of the patients had u11-dh $\mathrm{TxB}_{2}$ values lower than the cut-off value $(<1520$ $\mathrm{pg} / \mathrm{mg}$ creatinine) for aspirin therapeutic response. ${ }^{72}$

\section{Clinical Studies}

In an observational cohort study of adult patients with COVID-19, aspirin use at least 7 days before hospitalization or within 24 hours of hospitalization $(\mathrm{n}=98)$ compared to non-aspirin use $(n=314)$ was associated with lower rates of mechanical ventilation ( $36 \%$ vs $48 \%$,) and intensive care unit (ICU) admission (39\% vs $51 \%) .{ }^{73}$ In a multivariate analysis, aspirin use remained significantly associated with decreased risk of mechanical ventilation (adjusted hazard ratio [HR], 0.56; 95\% CI, 0.37 to 0.85 ; $\mathrm{p}=0.007$ ), ICU admission (adjusted HR, 0.57; 95\% CI, 0.38 to $0.85 ; \mathrm{p}=0.005)$, and in-hospital mortality (adjusted HR, 0.53; 95\% CI, 0.31 to $0.90 ; \mathrm{p}=0.02$ ). There were no differences in overt thrombosis or major bleeding between groups. ${ }^{73}$ This study provided the initial clinical evidence supporting aspirin use in patients with COVID-19. Most of these patients were on $81 \mathrm{mg}$ per day low-dose aspirin therapy. However, in the presence of a highly elevated inflammatory response, endothelial dysfunction, and hypercoagulability, low-dose aspirin therapy may not be adequate to produce the strong pharmacodynamic effects needed that can be translated into improved clinical outcomes.

In a study of American veterans with COVID-19, preexisting aspirin prescription was associated with a significant decrease in overall mortality at 14- days $(\mathrm{n}=35,370)(\mathrm{OR}=0.38,95 \% \mathrm{CI}=0.33-0.45)$ and at 30 -days $(\mathrm{n}=32,836) \quad(\mathrm{OR}=0.38 ; 95 \% \mathrm{CI}=0.33-0.45)$ compared to patients not treated with aspirin. ${ }^{74}$ Similarly, in a propensity score-matched observational study of COVID-19 patients $(\mathrm{n}=638)$, in-hospital aspirin compared to no antiplatelet therapy was associated with a significantly lower cumulative incidence of in-hospital death (HR, 0.52, $95 \% \mathrm{CI}) .{ }^{75}$ In another retrospective population-based crosssectional investigation (COVID-19-positive patients, $\mathrm{n}=$ 682 and COVID-19-negative patients, $\mathrm{n}=9815$ ), aspirin users had a lower rate of COVID-19 as compared to aspirin non-users (OR, $0.71 ; 95 \% \mathrm{CI}, 0.52$ to $0.99 ; \mathrm{p}=0.04$ ), and a shorter clinical duration of COVID-19 $(19.8 \pm 7.8$ vs 21.9 \pm 7.9 days, $\mathrm{p}=0.045){ }^{76}$

Similarly, other studies also have demonstrated the reduced mortality with prior and in-hospital use of aspirin. ${ }^{77,78}$ However, there were also reports of an absence or an elevated risk of mortality in COVID-19 patients. ${ }^{79-81}$ The reason for the latter absence of mortality benefits with aspirin use is not clearly understood at this time. Finally, prior use of 75-325 mg daily aspirin was associated with reduced mortality (RR $0.46 ; 95 \% \mathrm{CI}=$ $0.35, \quad 0.610, \quad \mathrm{p}<0.001)$ and in-hospital mortality $(\mathrm{RR}=0.39 ; 95 \% \mathrm{CI}=0.16-0.96 ; \mathrm{p}<0.001)$ (Table 2). ${ }^{82}$

Currently, multiple studies are exploring aspirin therapy alone or as an adjunctive agent in COVID-19 (NCT04808895, NCT04363840, NCT04365309, NCT04 324463, NCT04498273, NCT04466670, NCT04368377, 
Table I Studies of Aspirin Therapy in Patients with Acute Respiratory Distress Syndrome

\begin{tabular}{|c|c|c|c|c|}
\hline & Study & $\begin{array}{c}\text { Aspirin or Other } \\
\text { Antiplatelet Therapy }\end{array}$ & Outcomes & Comments \\
\hline \multirow[t]{2}{*}{$\begin{array}{l}\text { Panka BA } \\
\text { et al. } \\
\text { Systematic } \\
\text { review and } \\
\text { meta-analysis. } \\
2017^{59}\end{array}$} & $\begin{array}{l}\text { I5 Lung injury } \\
\text { model/preclinical } \\
\text { studies in mice, } \\
\text { sheep and dogs }\end{array}$ & $10-125 \mathrm{mg}$ aspirin $/ \mathrm{kg}$ & $\begin{array}{l}\text { Beneficial effect of antiplatelet drug } \\
\text { on ARDS reported in I } 3 \text { studies- } \\
\text { improved oxygenation, diminished } \\
\text { lung edema, inflammation, and in } \\
\text { some an increased survival }\end{array}$ & $\begin{array}{l}\text { Aspirin-triggered lipoxin reduced } \\
\text { inflammation and attenuated } \\
\text { edema; AT-RvDI- and COX- } \\
\text { dependent inhibitory effects were } \\
\text { also suggested. }\end{array}$ \\
\hline & $\begin{array}{l}\text { Meta-analysis of } 3 \\
\text { clinical studies in } \\
\text { patients with } \\
\text { ARDS }(n=5 \mid 55)\end{array}$ & Prior aspirin use & $\begin{array}{l}\text { Aspirin use was associated with } \\
\text { lower incidence of ARDs (OR=0.59; } \\
95 \% \mathrm{Cl}=0.36-0.98)\end{array}$ & $\begin{array}{l}\text { A potential beneficial role for } \\
\text { aspirin in ARDS prevention and } \\
\text { treatment }\end{array}$ \\
\hline $\begin{array}{l}\text { Liang } \mathrm{H} \text { et al. } \\
\text { Systematic } \\
\text { review and } \\
\text { meta-analysis. } \\
2020^{65}\end{array}$ & $\begin{array}{l}7 \text { Studies in } \\
\text { patients with } \\
\text { ARDS }(n=6764)\end{array}$ & Prior aspirin use & $\begin{array}{l}\text { Aspirin use was associated with } \\
\text { lower incidence of } A R D s \text { in at-risk } \\
\text { patients }(\mathrm{OR}=0.78 ; 95 \% \mathrm{Cl}=0.64- \\
0.96 ; \mathrm{p}=0.018) \text { and was not } \\
\text { associated with in-hospital mortality } \\
(\mathrm{OR}=0.88 ; 95 \% \mathrm{Cl}=0.73-1.07 ; \mathrm{p}= \\
0.204)\end{array}$ & $\begin{array}{l}\text { A potential beneficial role for } \\
\text { aspirin in ARDS prevention. }\end{array}$ \\
\hline $\begin{array}{l}\text { Harr JN et al. } \\
\text { Multicenter } \\
\text { study. } 2013^{66}\end{array}$ & $\begin{array}{l}\text { Severely injured } \\
\text { blunt trauma } \\
\text { patients at risk for } \\
\text { multiple organ } \\
\text { failure }(n=839)\end{array}$ & $\begin{array}{l}\text { I5\% of the patients on APT } \\
\text { of which } 66 \% \text { on aspirin }\end{array}$ & $\begin{array}{l}\text { Transfused patients on APT had } \\
\text { significantly lower ORs of lung } \\
\text { dysfunction and multiple organ } \\
\text { failure vs patients not on APT at } \\
\text { time of injury (interaction PRBC } \times \\
\text { APT, } P=0.0 \text { I for lung dysfunction, } \\
P=0.03 \text { for MOF). }\end{array}$ & $\begin{array}{l}\text { A potential beneficial role for } \\
\text { aspirin in blunt trauma patients at } \\
\text { risk for MOF. }\end{array}$ \\
\hline $\begin{array}{l}\text { O'Neal HR } \\
\text { et al. Cross- } \\
\text { sectional } \\
\text { analysis. } \\
2011^{67}\end{array}$ & $\begin{array}{l}\text { Critically ill } \\
\text { patients }(n=575)\end{array}$ & $\begin{array}{l}\text { In total, } 24 \% \text { patients on } \\
\text { aspirin and } 26 \% \text { on statins } \\
\text { before hospitalization; } 50 \% \\
\text { of statin treated patients on } \\
\text { aspirin }\end{array}$ & $\begin{array}{l}\text { Pre-hospital aspirin plus statin use } \\
\text { ( } 50 \% \text { of statin users) associated with } \\
\text { lowest rate of rates of ALI/ARDS, } \\
\text { severe sepsis, and hospital mortality. }\end{array}$ & $\begin{array}{l}\text { Prior aspirin use may provide } \\
\text { additional benefit in the presence } \\
\text { of statins in ALI/ARS patients }\end{array}$ \\
\hline $\begin{array}{l}\text { Chen W et al, } \\
\text { Propensity- } \\
\text { adjusted } \\
\text { analysis. } \\
2015^{68}\end{array}$ & $\begin{array}{l}\text { Critically ill } \\
\text { patients admitted } \\
\text { to ICU }(n=1149)\end{array}$ & $\begin{array}{l}25 \% \text { of the patients on prior } \\
\text { aspirin }\end{array}$ & $\begin{array}{l}\text { Prior aspirin use was associated with } \\
\text { lower prevalence of } A R D S(27 \% \text { vs } \\
34 \% \text { no prior aspirin, } \mathrm{P}=0.034) \text {, and } \\
\text { independently associated with } \\
\text { a decreased risk of } A R D s \text { (OR= } \\
0.66 ; 95 \% \mathrm{Cl}=0.46-0.94) \text { in the } \\
\text { entire cohort and in a subgroup of } \\
725 \text { patients with sepsis (OR= } 0.60 \text {; } \\
95 \% \mathrm{Cl}=0.4 \mathrm{I}-0.90) \text {. }\end{array}$ & - \\
\hline $\begin{array}{l}\text { Trauer J et al. } \\
\text { Propensity } \\
\text { analysis. } \\
2017^{69}\end{array}$ & $\begin{array}{l}6823 \text { Patients with } \\
\text { sepsis from II } \\
\text { studies }\end{array}$ & Prior aspirin use & $\begin{array}{l}\text { Prior aspirin use was associated with } \\
7 \% \text { reduction in mortality } \\
(p=0.0023)\end{array}$ & - \\
\hline
\end{tabular}

Abbreviations: APT, antiplatelet therapy; PRBC, packed red blood cells; OD, odds ratio; $\mathrm{Cl}$, confidence interval; ALI/ARDS, acute lung injury/acute respiratory distress syndrome; MOF, multiorgan failure; ICU, intensive care unit; COX, cyclooxygenase; AT-RvDI, aspirin-triggered resolvin DI.

NCT04410328, NCT04381936, NCT04333407), but none of these studies are focused on high-dose aspirin $(325 \mathrm{mg}$ per day) in COVID-19.
In the RECOVERY Trial, a multinational, randomized trial hospitalized COVID-19 patients who were treated with $150 \mathrm{mg}$ aspirin $(\mathrm{n}=7351)$ as compared to usual care 
Table 2 Studies of Aspirin Therapy in Patients with Coronavirus-19

\begin{tabular}{|c|c|c|c|c|}
\hline & Study & $\begin{array}{c}\text { Aspirin or Other } \\
\text { Antiplatelet Therapy }\end{array}$ & Outcomes & Comments \\
\hline $\begin{array}{l}\text { Chow JH et al } \\
\text { Retrospective, } \\
\text { observational study. } \\
2020^{73}\end{array}$ & $\begin{array}{l}\text { Hospitalized } \\
\text { COVID-19 patients } \\
(n=4 \mid 2)\end{array}$ & $\begin{array}{l}24 \% \text { of the patients on } \\
\text { aspirin }\end{array}$ & $\begin{array}{l}\text { Prior aspirin therapy independently } \\
\text { associated with less mechanical } \\
\text { ventilation (adjusted } \mathrm{HR}=0.56,95 \% \\
\mathrm{Cl}, 0.37-0.85, \mathrm{P}=00.007 \text { ), ICU } \\
\text { admission (adjusted } \mathrm{HR}, 0.57,95 \% \mathrm{Cl} \text {, } \\
0.38-0.85, \mathrm{P}=0.005 \text { ), and mortality } \\
\text { (adjusted } \mathrm{HR}, 0.53,95 \% \mathrm{Cl}, 0.3 \mathrm{I}-0.90 \text {, } \\
\mathrm{P}=00.02 \text { ). }\end{array}$ & $\begin{array}{l}\text { Prior aspirin use may improve } \\
\text { outcomes in hospitalized } \\
\text { COVID-19 patients }\end{array}$ \\
\hline $\begin{array}{l}\text { Osborne TF et al. } \\
\text { Veterans health } \\
\text { administration } \\
\text { study. } 2020^{74}\end{array}$ & $\begin{array}{l}\text { Patients with } \\
\text { COVID-19 } \\
(n=68,156)\end{array}$ & $\begin{array}{l}19 \% \text { of the patients on } \\
\text { aspirin }\end{array}$ & $\begin{array}{l}\text { Prior aspirin prescription was } \\
\text { associated with a decrease in overall } \\
\text { mortality at } 14 \text {-days }(\mathrm{OR}=0.38 ; 95 \% \mathrm{Cl} \\
0.32-0.46) \text { and at } 30 \text {-days }(\mathrm{OR}=0.38 \text {, } \\
95 \% \mathrm{Cl}=0.33-0.45)\end{array}$ & $\begin{array}{l}\text { Prior aspirin reduces } \\
\text { mortality in COVID-19 } \\
\text { patients }\end{array}$ \\
\hline $\begin{array}{l}\text { Meizlish } M \text { et al. } \\
\text { Propensity score- } \\
\text { matched analysis. } \\
2021^{75}\end{array}$ & $\begin{array}{l}\text { Hospitalized adult } \\
\text { COVID- } 19 \text { patients } \\
(n=2785)\end{array}$ & $\begin{array}{l}\text { In-hospital aspirin }= \\
\text { 1956; Propensity } \\
\text { matched cohort }=638\end{array}$ & $\begin{array}{l}\text { In-hospital aspirin vs no antiplatelet } \\
\text { therapy independently associated with } \\
\text { lower incidence of in-hospital death } \\
(\mathrm{HR}=0.52 ; 95 \% \mathrm{Cl}=0.336-0.8 \mathrm{I} 2 \\
\mathrm{P}=0.00 \mathrm{I})\end{array}$ & $\begin{array}{l}\text { In-hospital aspirin reduces } \\
\text { death }\end{array}$ \\
\hline $\begin{array}{l}\text { Merzon E et al. } \\
\text { Retrospective } \\
\text { population-based } \\
\text { cross-sectional } \\
\text { study. } 2021^{76}\end{array}$ & $\begin{array}{l}\text { COVID-19-positive } \\
(n=662) \text { and - } \\
\text { negative patients } \\
(n=9815)\end{array}$ & $\begin{array}{l}\text { Prior aspirin, COVID- } \\
\text { positive group }=11 \% \\
(n=73) \text { vs }- \text { negative } \\
\text { group }=16 \%(n=589) \\
(p=0.001) .\end{array}$ & 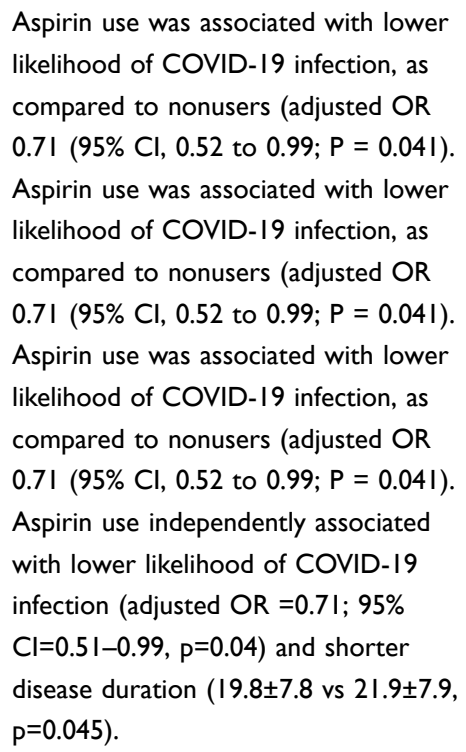 & $\begin{array}{l}\text { Prior aspirin was associated } \\
\text { lower likelihood of COVID- } \\
19 \text { infection and disease } \\
\text { duration. }\end{array}$ \\
\hline $\begin{array}{l}\text { Liu } Q \text { et al. } \\
\text { Propensity score- } \\
\text { matched analysis. } \\
2021^{77}\end{array}$ & $\begin{array}{l}\text { Hospitalized adult } \\
\text { COVID- } 19 \text { patients } \\
(n=232)\end{array}$ & $\begin{array}{l}\text { Hospitalized COVID-19 } \\
\text { patients on aspirin } \\
(n=28) \text { vs not on aspirin } \\
(n=204) .\end{array}$ & $\begin{array}{l}\text { Aspirin therapy was associated with } \\
\text { lower risk of } 30 \text {-day }(H R=0.19,95 \% \mathrm{Cl} \\
=0.05-0.78), p=0.021) \text { and } 60 \text {-day } \\
\text { mortality }(H R=0.25,0.07-0.87, p=0.03)\end{array}$ & $\begin{array}{l}\text { In-hospital aspirin therapy } \\
\text { reduces death }\end{array}$ \\
\hline $\begin{array}{l}\text { Haji Aghajani M, } \\
\text { Prospective study. } \\
2021^{78}\end{array}$ & $\begin{array}{l}\text { Hospitalized } \\
\text { COVID- } 19 \text { patients } \\
(n=991)\end{array}$ & $\begin{array}{l}\text { Patients with in-hospital } \\
\text { aspirin therapy }(n=336) \\
\text { and without aspirin } \\
\text { therapy }(n=655)\end{array}$ & $\begin{array}{l}\text { In-hospital aspirin therapy was } \\
\text { independently associated with reduced } \\
\text { in-hospital mortality }(\mathrm{HR}=0.74 ; 95 \% \\
\mathrm{Cl}=0.560-0.994) ; \mathrm{p}=0.046)\end{array}$ & $\begin{array}{l}\text { In-hospital aspirin therapy } \\
\text { reduces death }\end{array}$ \\
\hline
\end{tabular}

(Continued) 
Table 2 (Continued).

\begin{tabular}{|c|c|c|c|c|}
\hline & Study & $\begin{array}{c}\text { Aspirin or Other } \\
\text { Antiplatelet Therapy }\end{array}$ & Outcomes & Comments \\
\hline $\begin{array}{l}\text { Sahai A et al. } \\
\text { Propensity- } \\
\text { matched analyses. } \\
2021^{79}\end{array}$ & $\begin{array}{l}\text { Hospitalized } \\
\text { COVID-19 patients } \\
\text { treated with and } \\
\text { without aspirin } \\
(n=1994)\end{array}$ & $\begin{array}{l}\text { Patients on aspirin }=285, \\
\text { not on aspirin }=1709, \\
248 \text { propensity-matched } \\
\text { patients }\end{array}$ & $\begin{array}{l}\text { There were no differences in the } \\
\text { incidence of } \mathrm{Ml}(2.0 \% \text { vs } 0.8 \mathrm{I} \%) \mathrm{VTE} \\
(4.0 \% \text { vs I.6\%) and mortality (OR=0.85; } \\
95 \% \mathrm{Cl}=0.5 \mathrm{I}-\mathrm{I} .4 \mathrm{I} ; p=0.52)\end{array}$ & $\begin{array}{l}\text { No effect of aspirin therapy } \\
\text { on thrombotic events and } \\
\text { mortality }\end{array}$ \\
\hline $\begin{array}{l}\text { Yuan S et al. } \\
\text { Prospective study. } \\
2021^{80}\end{array}$ & $\begin{array}{l}\text { Hospitalized } \\
\text { COVID-19 patients } \\
\text { with coronary } \\
\text { artery disease } \\
(n=183)\end{array}$ & $\begin{array}{l}\text { Patients with prior } \\
\text { aspirin }(n=52) \text { vs without } \\
\text { aspirin }(n=|3|) \text {. }\end{array}$ & $\begin{array}{l}\text { No difference in in-hospital mortality } \\
\text { between patients with aspirin and } \\
\text { without aspirin ( } 21.2 \% \text { vs } 22.1 \%, P=0 \\
0.885) \text {. }\end{array}$ & $\begin{array}{l}\text { No influence of prior aspirin } \\
\text { use on in -hospital mortality } \\
\text { in COVID-19 patients with } \\
\text { coronary artery disease. }\end{array}$ \\
\hline $\begin{array}{l}\text { Reese JT et al. } \\
\text { Retrospective, } \\
\text { multi-center } \\
\text { observational study } \\
2021^{81}\end{array}$ & $\begin{array}{l}\text { Aspirin use in the } \\
\text { osteoarthritis } \\
\text { cohort }\end{array}$ & $\begin{array}{l}\text { COVID-19 patients with } \\
\text { osteoarthritis }(n=2266)\end{array}$ & $\begin{array}{l}\text { Aspirin use was associated with } \\
\text { increased mortality }(\mathrm{OR}=3.25,95 \% \\
\mathrm{Cl}=2.76-3.83)\end{array}$ & $\begin{array}{l}\text { Aspirin therapy was } \\
\text { associated with elevated } \\
\text { mortality }\end{array}$ \\
\hline $\begin{array}{l}\text { Martha JW et al. } \\
\text { Systematic review } \\
\text { and meta-analysis. } \\
2021^{82}\end{array}$ & & $\begin{array}{l}\text { Six studies with pre- } \\
\text { hospital } 75-325 \mathrm{mg} \text { daily } \\
\text { aspirin use in COVID-19 } \\
\text { patients }(n=\mid 3,993)\end{array}$ & $\begin{array}{l}\text { Prior aspirin use was associated with } \\
\text { reduced mortality }(\mathrm{RR}=0.46 ; 95 \% \mathrm{Cl}= \\
0.35,0.6 \mathrm{I} 0, \mathrm{p}<0.00 \mathrm{I}) \text { and in-hospital } \\
\text { mortality ( } \mathrm{RR}=0.39 ; 95 \% \mathrm{Cl}=0.16-0.96 \text {; } \\
\mathrm{p}<0.00 \mathrm{I}) \text {. }\end{array}$ & $\begin{array}{l}\text { Prior-aspirin use was } \\
\text { associated with total and in- } \\
\text { hospital mortality. }\end{array}$ \\
\hline
\end{tabular}

$(\mathrm{n}=7541)$ had a similar rate of death in 28 days $(17 \%$ in each group, rate ratio $=0.96 ; 95 \% \mathrm{CI}=0.89-1.04 ; 41$ $\mathrm{p}=0.35$ ) and there was no reduction in the risk of progression to the composite endpoint of invasive mechanical ventilation or death in patients not on invasive mechanical ventilation at baseline. However, $150 \mathrm{mg}$ aspirin therapy was associated with a $0.6 \%$ absolute reduction in thromboembolic events and a $0.6 \%$ increase in major bleeding. Interestingly, aspirin therapy was associated with nonsignificant shorter duration of hospitalization (median 8 vs 9 days), a significantly higher percentage of patients discharged from hospital alive within 28 days (75\% vs $74 \%$; rate ratio $1.06 ; 95 \%$ CI $1.02-1.10 ; \mathrm{p}=0.0062) .{ }^{81}$ In the absence of strong evidence, the treating physician should be cautious about recommending optimal dose aspirin in COVID-19 patients.

There are some caveats in this study. First, 7351 patients were randomized to the aspirin group, where $90 \%$ of those received at least one dose in the intention to treat (ITT) analysis. Thus, about $10 \%$ of the patients in the aspirin group did not receive any aspirin treatment, while $3 \%$ of the non-aspirin group did. Moreover, $12.5 \%$ mortality reduction was hypothesized, and according to this estimation, the aspirin subgroup was closed as "sufficient" patients had been recruited. Clearly, the difference at day 28 is small, but it might separate at later time points. A total observation period of 6 months was announced for several types of drug treatment, unfortunately not for the aspirin group, and also there is no discussion on ontreatment analysis. Secondly, patients were all on highdose infractionated heparin/low-molecular-weight heparin (UFH/LMWH) and are at markedly reduced thrombin levels, although one has to consider that the half-life of UFH is only 2 hours and its effect is highly variable. ${ }^{81}$ Importantly, in the absence of any pharmacodynamic assessment of aspirin, it is not clear whether $150 \mathrm{mg}$ daily aspirin dose is sufficient to inhibit thromboxane synthesis in the presence of hypercoagulability, very high levels of inflammation, and endothelial dysfunction. An easy tool to test this would be the measurement of $\mathrm{u} 11-\mathrm{dh}-\mathrm{Tx} \mathrm{B}_{2}$. Moreover, up to $3 \mathrm{~g}$ daily oral aspirin dose in adults and up to $2 \mathrm{~g}$ daily in the elderly ( $>65$ years) are approved medications for the treatment of flu-like symptoms in Germany. Interestingly, the dose issue is not mentioned as a possible explanation for a less-than-expected $(12.5 \%)$ reduced mortality by the authors. Therefore, adequately 
controlled and appropriately sized prospective randomized study is needed to support the results of the RECOVERY trial.

Taken together, the study does not sufficiently answer the question of whether $150 \mathrm{mg}$ aspirin might be beneficial in the treatment of SARS-COV-2 or not. However, it tends to suggest that aspirin on the background of anticoagulants might add some therapeutic benefit as seen here from the reduced in-hospital stay. The results again indicate that a higher dose (325 mg during hospital stay) may be more associated with more efficient antithrombotic and antiinflammatory effects accompanied by improved clinical outcomes. But the potential increase in bleeding may be a concern. Therefore, the administration of inhaled aspirin may be an effective option during the early period of hospitalization since the latter strategy may be associated with lesser bleeding. Finally, since hospitalized patients in the RECOVERY trial are treated with "usual" care with adequate antiplatelet and anti-inflammatory agents in addition to mechanical ventilation, a $325 \mathrm{mg}$ aspirin may be an effective option, particularly in underserved communities and remote areas of the world where immediate in-hospital treatment and other drugs are readily available.

The RECOVERY (Randomized Evaluation of COVID19 Therapy) study is evaluating the impact of aspirin on all-cause mortality among hospitalized patients with COVID-19 and is the largest adaptive platform randomized clinical trial for COVID-19 with 20,000 participants (NCT043819). The RECOVERY II (Randomized Evaluation of COVID-19 Therapy II) trial is now being planned to test the effectiveness of low-dose aspirin as an anti-inflammatory and antithrombotic treatment in COVID-19 patients (NCT04381936).

\section{Aerosolized Aspirin for the Acute Treatment of COVID-I9}

In the above-mentioned studies, a conventional $81-325 \mathrm{mg}$ daily aspirin dose was largely used. Systemic concentrations of aspirin and salicylic acid obtained by conventional oral aspirin doses mentioned above may not reach the airway and alveolus at a level needed for meaningful antiviral effects. The concentrations of aspirin needed for sufficient deposition in the lungs to attenuate rapid viral replication and thrombotic risk in the presence of cytokine storm, hypercoagulability and microthrombosis in patients with COVID-19 likely will not be reached following 81-325 $\mathrm{mg}$ daily oral dose. Moreover, high oral aspirin doses can be limited by salicylate uncoupling of oxidative phosphorylation at antiinflammatory doses. ${ }^{83}$ Aspirin may also cause respiratory irritation at high levels due to acidic properties. The LASAG can be administered directly as an aerosol and has been evaluated in clinical studies of chronic obstructive pulmonary disease (COPD) and influenza. ${ }^{84,85} \mathrm{D}$, L-lysine improves the stability and tolerability of inhaled aspirin, whereas glycine further increases stability. ${ }^{86}$ LASAG dissociates readily after topical administration and the pharmacodynamic properties of LASAG are similar to aspirin. ${ }^{88}$

LASAG was effective at inhibiting coronavirus replication in an in vitro cell system infected with either a low (human corona virous (HCoV)-229E) or high pathogenic strain (Middle East Respiratory Syndrome (MERS)$\mathrm{CoV}) .{ }^{87}$ Virus-induced NF- $\mathrm{BB}$ activity was attenuated early in the viral replication cycle by LASAG in highly pathogenic avian influenza virus strains leading to reduced viral titers, decreased viral protein accumulation, viral ribonucleic acid (RNA) synthesis, and impaired formation of viral replication transcription complexes. ${ }^{88}$

Nebulized LASAG three times a day to achieve a total daily alveolar dose of $133.5 \mathrm{mg}$ in 24 patients afflicted with severe influenza was found to be associated with faster alleviation of symptoms versus controls. ${ }^{85}$ LASAG is currently available and approved for intravenous administration in Germany. Up to $750 \mathrm{mg}$ twice-daily LASAG administration has been shown to be well tolerated and to decrease inflammation markers when inhaled by patients with chronic obstructive pulmonary disease. ${ }^{85}$

An inhaled nanoparticle aspirin formulation that can be administered as a dry powder inhaler to enhance the speed of platelet inhibition is under development. ${ }^{88}$ In a recent pilot, Phase 1, open-label, single dose-escalation study, the inhalation formulation of aspirin compared to chewing and swallowing soluble aspirin formulation is associated with earlier drug exposure (2-4 minutes versus $30 \mathrm{~min}$ utes, respectively) and earlier greater inhibition of arachidonic acid-induced platelet inhibition ( 2 minutes versus 40 minutes, respectively). ${ }^{89}$ Treatment with the above two inhaled formulations of aspirin may attenuate serious symptoms in COVID-19 during initial acute conditions.

With respect to safety concerns, high-dose aspirin as an adjunctive therapy with other agents has been associated with elevated risk for bleeding particularly gastrointestinal bleeding. COVID-19 is characterized by hypercoagulability and prothrombotic nature, the risk bleeding may not be a major concern. The risk bleeding may be lower with inhaled aspirin formulation. 


\section{Conclusions}

Aspirin exerts plural effects that position it as an ideal pharmacologic agent to treat COVID-19. These effects include anti-inflammation, antithrombosis, and antiviral properties that are mediated through two key pathways: the inhibition of IKK kinase and the inhibition of COX. Other non-canonical pathways such as acetylation of endothelial nitric oxide synthase (eNOS)NOS, endothelial protection and upregulation of heme oxygenase- 1 that are involved in protection from oxygen radicals may also play a role in modulating the inflammatory and prothrombotic responses observed in COVID-19. Optimal dose of aspirin to treat COVID-19 is critically dependent on the disease state. In patients who are hospitalized for COVID-19, readily available high-dose aspirin $(325 \mathrm{mg} /$ day $)$ in addition to other standard medications may attenuate high inflammation and thrombotic risk. Aspirin effects may be enhanced by aerosol delivery to the lung that is the key organ damaged in COVID-19. The inhaled formulation with rapid effects may be an effective strategy during the critical initial course of the disease, but studies are ongoing with these formulations. For long-term treatment in post-COVID-19 scenario, $325 \mathrm{mg}$ per day can be used to prevent recurrent thrombotic event occurrences. Further clinical studies are required to support this suggestion. However, low dose $(75-162 \mathrm{mg} /$ day) is not optimal to attenuate the high inflammation and platelet function as has been demonstrated in recent pharmacodynamic studies. Therefore, the low-dose aspirin may not be associated with significant clinical benefits. Elevated bleeding risk associated with higher dose of aspirin may be a major limitation. COVID-19 is a hypercoagulable disease with lower risk for bleeding, the net outcomes may favor towards attenuating thrombotic risk. In the recent prospective ROCOVERY trial, aspirin use was associated with an elevated bleeding risk. There are many limitations to this study discussed earlier and the study results have not been published in a peer reviewed journal yet.

Being a widely available, inexpensive drug with multiple proven benefits, aspirin can be exploited globally, particularly in underserved communities and remote areas of the world, to combat the ongoing COVID-19 pandemic. Furthermore, by being uninfluenced by viral mutagenesis in its unique mechanisms of action, aspirin holds the promise of being a strong ally in the fight against our new enemy and other viruses that will certainly follow.

\section{Author Contributions}

All authors contributed to data analysis, drafting or revising the article, have agreed on the journal to which the article will be submitted, gave final approval of the version to be published, and agree to be accountable for all aspects of the work.

\section{Funding}

Platelet and Thrombosis Research, LLC, Baltimore, MD, USA.

\section{Disclosure}

Dr Tantry received Honoraria from UpToDate and AggreGuide. Dr Gurbel has received consulting fees and/ or honoraria from Bayer, Otitopic, Janssen, UpToDate, US WorldMeds, Hikari Dx, and Medicure; institutional research grants from the National Institutes of Health, Haemonetics, Bayer, Medicure, Instrumentation Laboratories, US WorldMeds, Amgen, Idorsia, Otitopic, and Janssen. Dr Schror has received personal fees from Bayer, during the conduct of the study. The authors report no other conflicts of interest in this work.

\section{References}

1. Bikdeli B, Madhavan MV, Jimenez D, et al. COVID-19 and thrombotic or thromboembolic disease: implications for prevention, antithrombotic therapy, and follow-up: JACC state-of-the-art review. $\mathrm{J} \mathrm{Am} \mathrm{Coll}$ Cardiol. 2020;75(23):2950-2973. doi:10.1016/j.jacc.2020.04.031

2. Cuker A, Tseng EK, Nieuwlaat R, et al. American Society of Hematology 2021 guidelines on the use of anticoagulation for thromboprophylaxis in patients with COVID-19. Blood Adv. 2021;5:872-888. doi:10.1182/bloodadvances.2020003763

3. Bianconi V, Violi F, Fallarino F, Pignatelli P, Sahebkar A, Pirro M. Is acetylsalicylic acid a safe and potentially useful choice for adult patients with COVID-19? Drugs. 2020;80:1383-1396. doi:10.1007/ s40265-020-01365-1

4. Grabowski F, Preibisch G, Giziński S, et al. SARS-CoV-2 variant of concern 202012/01 has about twofold replicative advantage and acquires concerning mutations. Viruses. 2021;1(13):392. doi:10.3390/ v13030392

5. Harrison AG, Lin T, Wang P. Mechanisms of SARS-CoV-2 transmission and pathogenesis. Trends Immunol. 2020;41:1100-1115. doi:10.1016/j.it.2020.10.004

6. Walls AC, Park YJ, Tortorici MA, et al. Structure, function, and antigenicity of the SARS-CoV-2 spike glycoprotein. Cell. 2020;181:281-292. doi:10.1016/j.cell.2020.02.058

7. Kircheis R, Haasbach E, Lueftenegger D, et al. NF- $\kappa \mathrm{B}$ pathway as a potential target for treatment of critical stage COVID-19 patients. Front Immunol. 2020;11:598444. doi:10.3389/fimmu.2020.598444

8. He L, Ding Y, Zhang Q, et al. Expression of elevated levels of pro-inflammatory cytokines in SARS-CoV-infected ACE2+ cells in SARS patients: relation to the acute lung injury and pathogenesis of SARS. J Pathol. 2006;210:288-297. doi:10.1002/path.2067

9. Poppe M, Wittig S, Jurida L, et al. The NF-kB-dependent and independent transcriptome and chromatin landscapes of human coronavirus 229E-infected cells. PLoS Pathog. 2017;13:e1006286. doi:10.1371/journal.ppat.1006286 
10. Jayarangaiah A, Kariyanna PT, Chen X, et al. COVID-19-associated coagulopathy: an exacerbated immunothrombosis response. Clin Appl Thromb Hemost. 2020;26:1076029620943293. doi:10.1177/ 1076029620943293

11. Hue S, Beldi-Ferchiou A, Bendib I, et al. Uncontrolled Innate and Impaired adaptive immune responses in patients with COVID-19 acute respiratory distress syndrome. Am J Respir Crit Care Med. 2020;202:1509-1519. doi:10.1164/rccm.202005-1885OC

12. Yadav H, Kor DJ. Platelets in the pathogenesis of acute respiratory distress syndrome. Am J Physiol Lung Cell Mol Physiol. 2015;309: L915-23. doi:10.1152/ajplung.00266.2015

13. Zhang S, Liu Y, Wang X, et al. SARS-CoV-2 binds platelet ACE2 to enhance thrombosis in COVID-19. J Hematol Oncol. 2020;13:120. doi:10.1186/s13045-020-00954-7

14. Kreutz RP, Tantry US, Bliden KP, Gurbel PA. Inflammatory changes during the 'common cold' are associated with platelet activation and increased reactivity of platelets to agonists. Blood Coagul Fibrinolysis. 2007;18:713-718. doi:10.1097/MBC.0b013e328201c77e

15. Gurbel PA, deFilippi CR, Bliden KP, Tantry US. HIV infection, ACS, PCI and high platelet reactivity: ingredients for a perfect thrombotic storm. Eur Heart J. 2017;38:1687-1689. doi:10.1093/eurheartj/ ehw630

16. Lefrançais E, Ortiz-Muñoz G, Caudrillier A, et al. The lung is a site of platelet biogenesis and a reservoir for haematopoietic progenitors. Nature. 2017;544:105-109. doi:10.1038/nature21706

17. Gustafson D, Raju S, Wu R, et al. Overcoming barriers: the endothelium as a linchpin of coronavirus disease 2019 pathogenesis? Arter Thromb Vasc Biol. 1818-1829;2020(40):548.

18. Helms J, Tacquard C, Severac F, et al.; CRICS TRIGGERSEP Group. High risk of thrombosis in patients with severe SARS-CoV-2 infection: a multicenter prospective cohort study. Intensive Care Med. 2020;46:1089-1098. doi:10.1007/s00134-020-06062-x

19. Connors JM, Levy JH. COVID-19 and its implications for thrombosis and anticoagulation. Blood. 2020;135:2033-2040. doi:10.1182/ blood.2020006000

20. Janiuk K, Jabłońska E, Garley M. Significance of NETs formation in COVID-19. Cells. 2021;10:151. doi:10.3390/cells10010151

21. Ackermann M, Verleden SE, Kuehnel M, et al. Pulmonary vascular endothelialitis, thrombosis, and angiogenesis in Covid-19. $N$ Engl $J$ Med. 2020;383:120-128. doi:10.1056/NEJMoa2015432

22. Do Espírito Santo DA, Lemos ACB, Miranda CH. In vivo demonstration of microvascular thrombosis in severe COVID-19. J Thromb Thrombolysis. 2020;50:790-794. doi:10.1007/s11239-020-02245-x

23. Satturwar S, Fowkes M, Farver C, et al. Postmortem findings associated with SARS-CoV-2: systematic review and meta-analysis. Am J Surg Pathol. 2021;45:587-603. doi:10.1097/PAS.0000000000001650

24. Gurbel PA, Bliden KP, Schrör K. Can an old ally defeat a new enemy? Circulation. 2020;142:315-317. doi:10.1161/ CIRCULATIONAHA.120.047830

25. Tantry US, Mahla E, Gurbel PA. Aspirin resistance. Prog Cardiovasc Dis. 2009;52:141-152. doi:10.1016/j.pcad.2009.05.001

26. Boutaud O, Sosa IR, Amin T, et al. Inhibition of the biosynthesis of prostaglandin E2 by low-dose aspirin: implications for adenocarcinoma metastasis. Cancer Prev Res. 2016;9:855-865. doi:10.1158/ 1940-6207.CAPR-16-0094

27. Tacconelli S, Contursi A, Falcone L, et al. Characterization of cyclooxygenase- 2 acetylation and prostanoid inhibition by aspirin in cellular systems. Biochem Pharmacol. 2020;178:114094. doi:10. 1016/j.bcp.2020.114094

28. Pepine CJ, Gurbel PA. Cardiovascular safety of NSAIDs: additional insights after PRECISION and point of view. Clin Cardiol. 2017;40:1352-1356. doi:10.1002/clc.22814

29. Bliden KP, Singla A, Gesheff MG, et al. Statin therapy and thromboxane generation in patients with coronary artery disease treated with high-dose aspirin. Thromb Haemost. 2014;112:323. doi:10.1160/ TH14-01-0094
30. Gurbel PA, Bliden KP, Tantry US. Defining platelet response to acetylsalicylic acid: the relation between inhibition of serum thromboxane B2 and agonist-induced platelet aggregation. J Thromb Thrombolysis. 2021;51:260-264. doi:10.1007/s11239-020-02334-x

31. Chaudhary R, Bliden KP, Garg J, et al. Statin therapy and inflammation in patients with diabetes treated with high dose aspirin. $J$ Diabetes Complications. 2016;30:1365-1370. doi:10.1016/j. jdiacomp.2016.05.002

32. Eikelboom JW, Hirsh J, Weitz JI, et al. Aspirin-resistant thromboxane biosynthesis and the risk of myocardial infarction, stroke, or cardiovascular death in patients at high risk for cardiovascular events. Circulation. 2002;105:1650-1655. doi:10.1161/01.CIR.0000013777. 21160.07

33. Eikelboom JW, Hankey GJ, Thom J, et al. Clopidogrel for High Atherothrombotic Risk and Ischemic Stabilization, Management and Avoidance (CHARISMA) Investigators. Incomplete inhibition of thromboxane biosynthesis by acetylsalicylic acid: determinants and effect on cardiovascular risk. Circulation. 2008;118:1705-1712. doi:10.1161/CIRCULATIONAHA.108.768283

34. Rocca B, Buck G, Petrucci G, et al.; The ASCEND Study Collaborative Group. Thromboxane metabolite excretion is associated with serious vascular events in diabetes mellitus: a sub-study of the ASCEND trial. Eur Heart J. 2020;41(2):ehaa946.2926. doi:10.1093/ehjci/ehaa946.2926

35. Ortiz-Muñoz G, Mallavia B, Bins A, et al. Aspirin-triggered 15-epilipoxin A4 regulates neutrophil-platelet aggregation and attenuates acute lung injury in mice. Blood. 2014;124:2625-2634. doi:10.1182/ blood-2014-03-562876

36. Paul-Clark MJ, Van Cao T, Moradi-Bidhendi N, et al. 15-epi-lipoxin A4-mediated induction of nitric oxide explains how aspirin inhibits acute inflammation. J Exp Med. 2004;200:69-78. doi:10.1084/ jem. 20040566

37. Nascimento-Silva V, Arruda MA, Barja-Fidalgo C, Fierro IM. Aspirin-triggered lipoxin A4 blocks reactive oxygen species generation in endothelial cells: a novel antioxidative mechanism. Thromb Haemost. 2007;97:88-98. doi:10.1160/TH06-06-0315

38. Taubert D, Berkels R, Grosser N, et al. Aspirin induces nitric oxide release from vascular endothelium: a novel mechanism of action. Br J Pharmacol. 2004;143(1):159-165. doi:10.1038/sj. bjp.0705907

39. Sun YP, Oh SF, Uddin J, et al. Resolvin D1 and its aspirin-triggered $17 \mathrm{R}$ epimer. Stereochemical assignments, anti-inflammatory properties, and enzymatic inactivation. J Biol Chem. 2007;282:9323-9334. doi:10.1074/jbc.M609212200

40. Eickmeier O, Seki H, Haworth O, et al. Aspirin-triggered resolvin D1 reduces mucosal inflammation and promotes resolution in a murine model of acute lung injury. Mucosal Immunol. 2013;6:256-266. doi:10.1038/mi.2012.66

41. Yin MJ, Yamamoto Y, Gaynor RB. The anti-inflammatory agents aspirin and salicylate inhibit the activity of I(kappa)B kinase-beta. Nature. 1998;396:77-80. doi:10.1038/23948

42. Frantz B, O'Neill EA. The effect of sodium salicylate and aspirin on NF-kappa B. Science. 1995;270:2017-2019. doi:10.1126/science.27 0.5244 .2017

43. Glatthaar-Saalmüller B, Mair KH, Saalmüller A. Antiviral activity of aspirin against RNA viruses of the respiratory tract-an in vitro study. Influenza Other Respir Viruses. 2017;11:85-92. doi:10.1111/ irv. 12421

44. Undas A, Brummel-Ziedins KE, Mann KG. Antithrombotic properties of aspirin and resistance to aspirin: beyond strictly antiplatelet actions. Blood. 2007;109:2285-2292. doi:10.1182/blood-2006-01010645

45. Undas A, Brummel-Ziedins K-E, Mann KG. Why does aspirin decrease the risk of venous thromboembolism? On old and novel antithrombotic effects of acetyl salicylic acid. $J$ Thromb and Haemost. 2014;12:1776-1787. doi:10.1111/jth.12728 
46. Tarantino E, Amadio P, Squellerio I, et al. Role of thromboxane-dependent platelet activation in venous thrombosis: aspirin effects in mouse model. Pharmacol Res. 2016;107:415-425. doi:10.1016/j.phrs.2016.04.001

47. Bailey MA, Aggarwal R, Bridge KI, et al. Aspirin therapy is associated with less compact fibrin networks and enhanced fibrinolysis in patients with abdominal aortic aneurysm. Thromb Haemost. 2015;13:795-801. doi:10.1111/jth.12872

48. Tehrani S, Antovic A, Mobarrez F, et al. High-dose aspirin is required to influence plasma fibrin network structure in patients with type 1 diabetes. Diabetes Care. 2012;35:404-408. doi:10.2337/dc11-1302

49. Smith WL. The eicosanoids and their biochemical mechanisms of action. Biochem J. 1989;259:315-324. doi:10.1042/bj2590315

50. Wang J, Zhang CJ, Zhang J, et al. Mapping sites of aspirin-induced acetylations in live cells by quantitative acid-cleavable activity-based protein profiling (QA-ABPP). Sci Rep. 2015;5:7896. doi:10.1038/ srep07896

51. Choudhary C, Kumar C, Gnad F, et al. Lysine acetylation targets protein complexes and co-regulates major cellular functions. Science. 2009;325:834-840. doi:10.1126/science.1175371

52. Lapponi MJ, Carestia A, Landoni VI, et al. Regulation of neutrophil extracellular trap formation by anti-inflammatory drugs. J Pharmacol Exp Ther. 2013;345:430-437. doi:10.1124/jpet.112.202879

53. Chen CM, Tung YT, Wei $\mathrm{CH}$, et al. Anti-inflammatory and reactive oxygen species suppression through aspirin pretreatment to treat hyperoxia-induced acute lung injury in NF- $\kappa \mathrm{B}$-luciferase inducible transgenic mice. Antioxidants. 2020;9:429. doi:10.3390/antiox90 50429

54. Huang RT, Dietsch E. Anti-influenza viral activity of aspirin in cell culture. N Engl J Med. 1988;319:797.

55. Mazur I, Wurzer WJ, Ehrhardt C, Al ET. Acetylsalicylic acid (ASA) blocks influenza virus propagation via its NF-kappaB-inhibiting activity. Cell Microbiol. 2007;9:1683-1694. doi:10.1111/j.14625822.2007.00902.x

56. Zarbock A, Singbartl K, Ley K. Complete reversal of acid-induced acute lung injury by blocking of platelet-neutrophil aggregation. J Clin Invest. 2006;116:3211-3219. doi:10.1172/JCI29499

57. Chen CM, Lu HC, Tung YT, Chen W. Antiplatelet therapy for acute respiratory distress syndrome. Biomedicines. 2020;8:230. doi:10. 3390/biomedicines 8070230

58. Toner P, McAuley DF, Shyamsundar M. Aspirin as a potential treatment in sepsis or acute respiratory distress syndrome. Crit Care. 2015;19:374. doi:10.1186/s13054-015-1091-6

59. Panka BA, de Grooth HJ, Spoelstra-de Man AM, et al. Prevention or treatment of ardss with aspirin: a review of preclinical models and meta-analysis of clinical studies. Shock. 2017;47:13-21. doi:10.1097/ SHK.0000000000000745

60. Erlich JM, Talmor DS, Cartin-Ceba R, et al. Prehospitalization antiplatelet therapy is associated with a reduced incidence of acute lung injury: a population-based cohort study. Chest. 2011;139:289-295. doi:10.1378/chest.10-0891

61. Eisen DP, Reid D, McBryde ES. Acetyl salicylic acid usage and mortality in critically ill patients with the systemic inflammatory response syndrome and sepsis. Crit Care Med. 2012;40:1761-1767. doi:10.1097/CCM.0b013e318246b9df

62. Sossdorf M, Otto GP, Boettel J, et al. Benefit of low-dose aspirin and non-steroidal anti-inflammatory drugs in septic patients. Crit Care. 2013;17:402. doi:10.1186/cc11886

63. Boyle AJ, Di Gangi S, Hamid UI, et al. Aspirin therapy in patients with acute respiratory distress syndrome (ARDS) is associated with reduced intensive care unit mortality: a prospective analysis. Crit Care. 2015;19:1-8. doi:10.1186/s13054-015-0846-4

64. Kor DJ, Erlich J, Gong MN, et al. Association of prehospitalization aspirin therapy and acute lung injury: results of a multicenter international observational study of at-risk patients. Crit Care Med. 2011;39:2393-2400. doi:10.1097/CCM.0b013e318225757f
65. Liang H, Ding X, Li H, Li L, Sun T. Association between prior aspirin use and acute respiratory distress syndrome incidence in at-risk patients: a systematic review and meta-analysis. Front Pharmacol. 2020;19(11):738. doi:10.3389/fphar.2020.00738

66. Harr JN, Moore EE, Johnson J, et al. Antiplatelet therapy is associated with decreased transfusion-associated risk of lung dysfunction, multiple organ failure, and mortality in trauma patients. Crit Care Med. 2013;41:399-404. doi:10.1097/CCM.0b013e31826ab38b

67. O’Neal HR, Koyama T, Koehler EA, et al. Prehospital statin and aspirin use and the prevalence of severe sepsis and acute lung injury/ acute respiratory distress syndrome. Crit Care Med. 2011;39:1343-1350. doi:10.1097/CCM.0b013e3182120992

68. Chen W, Janz DR, Bastarache JA, et al. Prehospital aspirin use is associated with reduced risk of acute respiratory distress syndrome in critically ill patients: a propensity-adjusted analysis. Crit Care Med. 2015;43:801-807. doi:10.1097/CCM.0000000000000789

69. Trauer J, Muhi S, McBryde ES, et al. Quantifying the effects of prior acetyl-salicylic acid on sepsis-related deaths: an individual patient data meta-analysis using propensity matching. Crit Care Med. 2017;45:1871-1879. doi:10.1097/CCM.0000000000002654

70. Kiers D, van der Heijden WA, Al ET. A randomized trial on the effect of anti-platelet therapy on the systemic inflammatory response in human endotoxaemia. Thromb Haemost. 2017;117:1798-1807. doi:10.1160/TH16-10-0799

71. Gurbel PA, Bliden KP, Walia N, et al. Is low dose aspirin effective in reducing in-hospital clinical outcomes in patients with COVID-19? $J$ Am Coll Cardiol. 2021;77:3083. doi:10.1016/S0735-1097(21)04438-7

72. Gurbel PA, Bliden KP, Tantry US. Defining platelet response to acetylsalicylic acid: the relation between inhibition of serum thromboxane B2 and agonist-induced platelet aggregation. J Thromb Thrombolysis. 2021;51:260-264.

73. Chow JH, Khanna AK, Kethireddy S, et al. Aspirin use is associated with decreased mechanical ventilation, intensive care unit admission, and in-hospital mortality in hospitalized patients with coronavirus disease 2019. Anesth Analg. 2021;132:930-941. doi:10.1213/ ANE.0000000000005292

74. Osborne TF, Veigulis ZP, Arreola DM, et al. Association of mortality and aspirin prescription for COVID-19 patients at the Veterans Health Administration. PLoS One. 2021;16:e246825. doi:10.1371/ journal.pone. 0246825

75. Meizlish ML, Goshua G, Liu Y, et al. Intermediate-dose anticoagulation, aspirin, and in-hospital mortality in COVID-19: a propensity score-matched analysis. Am J Hematol. 2021;96:471-479. doi:10.1002/ ajh.26102

76. Merzon E, Green I, Vinker S, et al. The use of aspirin for primary prevention of cardiovascular disease is associated with a lower likelihood of COVID-19 infection. FEBS J. 2021;288(17):5179-5189. doi:10.1111/febs. 15784

77. Liu Q, Huang N, Li A, et al. Effect of low-dose aspirin on mortality and viral duration of the hospitalized adults with COVID-19. Medicine. 2021;100:e24544. doi:10.1097/MD.0000000 000024544

78. Haji Aghajani M, Moradi O, Amini H, et al. Decreased in-hospital mortality associated with aspirin administration in hospitalized patients due to severe COVID-19. J Med Virol. 2021;93 (9):5390-5395. doi:10.1002/jmv.27053

79. Sahai A, Bhandari R, Godwin M, et al. Effect of aspirin on short-term outcomes in hospitalized patients with COVID-19. Vasc Med;2021. 1358863X2110127. doi:10.1177/1358863X211012754

80. Yuan S, Chen P, Li H, et al. Mortality and pre-hospitalization use of low-dose aspirin in COVID-19 patients with coronary artery disease. J Cell Mol Med. 2021;25:1263-1273. doi:10.1111/jcmm.16 198

81. Reese JT, Coleman B, Chan L, et al. Cyclooxygenase inhibitor use is associated with increased COVID-19 severity. medRxiv. 2021; $1: 548$. 
82. Martha JW, Pranata R, Lim MA, et al. Active prescription of low-dose aspirin during or prior to hospitalization and mortality in COVID-19 - a systematic review and meta-analysis of adjusted effect estimates. Int J Infect Dis. 2021;1:00417.

83. Schrör K. Acetylsalicylic Acid. 2nd. ed, Schrör KK. Weinheim, Germany:Wiley-VCH Verlag GmbH \& Co; 2016

84. Scheuch G, Canisius S, Nocker K, et al. Targeting intracellular signaling as an antiviral strategy: aerosolized LASAG for the treatment of influenza in hospitalized patients. Emerg Microbes Infect. 2018;7:21. doi:10.1038/s41426-018-0023-3

85. Soleti A, Zuccari G, Omini C, et al. Aspirin inhalation treatment for COPD patients: preliminary studies on PK and inflammatory biomarkers. Eur Respiratory J. 2011;38(Supple55; p825):487.
86. Droebner K, Haasbach E, Dudek SE, et al. Pharmacodynamics, pharmacokinetics, and antiviral activity of BAY 81-8781, a novel NF-кB inhibiting anti-influenza drug. Front Microbiol. 2017;8:2130. doi:10.3389/fmicb.2017.02130

87. Kanani K, Gatoulis SC, Voelker M. Influence of differing analgesic formulations of aspirin on pharmacokinetic parameters. Pharmaceutics. 2015;7:188-198. doi:10.3390/pharmaceutics7030188

88. Muller C, Karl N, Ziebuhr J, Pleschka SDD. L-lysine acetylsalicylate + glycine impairs coronavirus replication. $J$ Antivir Antiretrovir. 2016;4:142-150.

89. Gurbel PA, Bliden KP, Chaudhary R, Tantry US. First in-human experience with inhaled acetylsalicylic acid for immediate platelet inhibition: comparison with chewed and swallowed acetylsalicylic acid. Circulation. 2020;142:1305-1307. doi:10.1161/CIRCULATIONAHA.120.047477

\section{Publish your work in this journal}

The Journal of Experimental Pharmacology is an international, peerreviewed, open access journal publishing original research, reports, reviews and commentaries on all areas of laboratory and experimental pharmacology. The manuscript management system is completely online and includes a very quick and fair peer-review system. Visit http://www.dovepress.com/testimonials.php to read real quotes from published authors. 